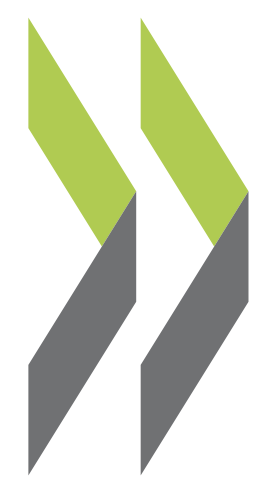

OECD Local Economic and Employment Development (LEED) Papers 2020/06

Labour demand weakening during the COVID-19 pandemic in US cities: Stylised facts and factors Alexandra Tsvetkova, Simone Grabner, Wessel Vermeulen related to regional resilience 


\section{Labour demand weakening during the COVID-19 pandemic in US cities}

\section{Stylised facts and factors related to regional resilience}

By Alexandra Tsvetkova, Simone Grabner and Wessel N. Vermeulen

This paper explores patterns of short-term labour demand weakening in Metropolitan Statistical Areas (MSAs) of the United States and the associated regional factors. The paper considers online job vacancy postings in February-June 2020. The data show that in larger MSAs, online job postings contracted more and the recovery was slower compared to smaller MSAs. Non-tradable service occupations, particularly those involving face-to-face interactions, contracted the most. The regression analysis reveals that different metropolitan characteristics were associated with the initial drop (February-April) and the recovery (MayJune) in online job posting. The associations of online job postings with regional characteristics also differed between teleworkable (with high feasibility of performing work duties remotely) and non-teleworkable jobs. Cities with higher share of teleworkable employment had more online vacancy announcements during the first months of the COVID-19 pandemic.

JEL codes: J23; J21; L16; R11

Keywords: labour demand, local labour markets, COVID-19, economic crisis, MSA, US

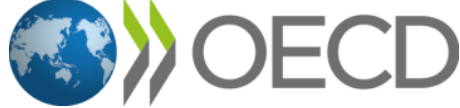




\section{ABOUT THE OECD}

The OECD is a multi-disciplinary inter-governmental organisation of 37 member countries which engages in its work an increasing number of non-members from all regions of the world. The Organisation's core mission today is to help governments work together towards a stronger, cleaner, fairer global economy. Through its network of 250 specialised committees and working groups, the OECD provides a setting where governments compare policy experiences, seek answers to common problems, identify good practice, and co-ordinate domestic and international policies. More information available: www.oecd.org.

\section{ABOUT OECD LOCAL ECONOMIC AND EMPLOYMENT DEVELOPMENT (LEED) PAPERS}

The OECD Local Economic and Employment Development (LEED) Programme Papers present innovative ideas and practical examples on how to boost local development and job creation. A wide range of topics are addressed, such as employment and skills; entrepreneurship; the social economy and social innovation; culture; and local capacity building, among others. The series highlights in particular policies to support disadvantaged places and people, such as the low skilled, the unemployed, migrants, youth and seniors.

OECD Working Papers should not be reported as representing the official views of the OECD or of its member countries. The opinions expressed and arguments employed are those of the author(s).

Working Papers describe preliminary results or research in progress by the author(s) and are published to stimulate discussion on a broad range of issues on which the OECD works. Comments on Working Papers are welcome, and may be sent to the Centre for Entrepreneurship, SMEs, Regions and Cities, OECD, 2 rue André-Pascal, 75775 Paris Cedex 16, France.

This paper is authorised for publication by Lamia Kamal-Chaoui, Director, Centre for Entrepreneurship, SMEs, Regions and Cities, OECD.

This document, as well as any statistical data and map included herein, are without prejudice to the status of or sovereignty over any territory, to the delimitation of international frontiers and boundaries and to the name of any territory, city or area.

(C) OECD 2020

You can copy, download or print OECD content for your own use, and you can include excerpts from OECD publications, databases and multimedia products in your own documents, presentations, blogs, websites and teaching materials, provided that suitable acknowledgement of OECD as source and copyright owner is given. All requests for public or commercial use and translation rights should be submitted to rights@oecd.org. 


\section{Acknowledgements}

The authors thank colleagues at the Centre for Entrepreneurship, SMEs, Regions and Cities (CFE) Karen Maguire (Local Employment, Skills and Social Innovation (LESI) Division) as well as Rudiger Ahrend and Alexander Lembcke (both in Economic Analysis, Statistics and Multilevel Governance Section) for their detailed comments and support. Andrea Bassanini, Fabio Manca, Elena Crivellaro, Luca Marcolin and Andrea Garnero of the OECD Directorate for Employment, Labour and Social Affairs offered many suggestions that improved the paper. Elisa Campestrin (OECD Trento Centre for Local Development) helped with editing and formatting the document. 


\section{Table of contents}

Acknowledgements 3

1. Introduction and key findings $\quad 5$

2. Stylised facts 6

3. Empirical Analysis 12

$\begin{array}{ll}\text { Concluding remarks } & 22\end{array}$

$\begin{array}{ll}\text { References } & 23\end{array}$

Annex A. Separate estimation for teleworkable and nonteleworkable occupations $\quad 26$

\section{Tables}

Table 2.1. Occupational taxonomy of performance during the contraction and recovery phases 10

Table 2.2. Population and employment in US MSAs, 2019

Table 3.1. Summary statistics for the dependent variable $\quad 13$

Table 3.2. Description of independent variables $\quad 14$

Table 3.3. Summary statistics for the independent variables $\quad 16$

Table 3.4. Teleworkable occupations at 2-digit SOC code $\quad 18$

Table 3.5. Estimation results, MSA aggregated $\quad 19$

Table 3.6. Estimation results, MSA-occupation pairs 20

\section{Figures}

Figure 2.1. Job announcements in US Metropolitan Statistical Areas, first semester 2019 and 2020

Figure 2.2. Total job announcements in occupations with largest and smallest decline (January 2020=100) 9

Figure 2.3. Total job announcements in US MSAs by size (January=100), first semester 2019 and 2020

\section{Boxes}

Box 2.1. List of occupational groups used in the analysis 


\section{Introduction and key findings}

The ongoing crisis caused by the COVID-19 pandemic is like no other in recent history. A local health emergency spread quickly across the globe forcing governments to introduce stay-at-home orders, halt transportation connections and temporary close many businesses. This translated in a deep economic recession with disruptions happening simultaneously at many levels and within many sectors. As a result, prior experience of dealing with crises became less clear-cut. The new reality calls for new solutions in the organisation of social and economic life around the globe, among other measures.

Labour market performance is one example of the crisis unfolding in an unprecedented way, where a combination of the old and the new ways of addressing the downturn is likely to hold promise. This paper explores labour demand weakening in United States (US) Metropolitan Statistical Areas (MSAs). The analysis provides an illustration of how the current situation is different from the past and offers preliminary evidence on the promise of teleworking for urban labour markets.

The crisis has had a rapid and devastating effect on labour markets across the world. In the US, labour demand collapsed in the second half of March 2020 (Kahn, Lange and Wiczer, 2020[1]) but the decline was uneven across regions (OECD Spatial Productivity Lab, 2020[2]). This paper documents the patterns of labour demand weakening using the data on online job postings provided by Burning Glass Technologies and identifies regional characteristics associated with labour market performance.

Two main conclusions follow from the analysis. First, the ongoing crisis is very different from the previous ones. Places that were more resilient in past downturns appear to suffer deeper declines in labour demand, at least in the initial phase between February and June 2020. For example, small MSAs (less than 500 000 residents in 2019) outperformed their larger counterparts in maintaining labour demand as reflected in online vacancy announcements. The regression analysis suggests that online postings decreased more than what would be expected given the 2019 trends in more educated MSAs and MSAs with a more diversified (intrasectoral) industrial structure. Both these factors were linked in the past recession to greater resilience. Second, teleworkability (share of jobs that can be performed remotely) emerges as a factor associated with a smaller contraction of online vacancy announcements in US MSA during the COVID-19 pandemic. 


\section{Stylised facts}

This section discusses trends in aggregate labour demand (approximated by monthly total online vacancy announcements) from January to June 2020 in US MSAs. It first presents national overall trends followed by trends by occupation and by MSA size. ${ }^{1}$

\section{National trends}

The first case of COVID-19 in the United States was confirmed on 21 January 2020. As the virus was quickly spreading in China, the US introduced restrictions on arrivals from Chinese mainland on 31 January. This followed by national and state-wide guidelines in March to avoid travel and for people to work from home whenever possible. Many more states imposed similar notices by the end of March and by early April, the majority of US population were subject to stay-at-home orders (Taylor, 2020 ${ }_{[3]}$ ), which were subsequently lifted at different points in time. Unemployment skyrocketed with 6.6 million applications for unemployment benefits during the last week of March, which was almost 10 times the previous record for the number of applications in a single week.

Figure 2.1 shows the total monthly number of new online job announcements in all US MSAs and the time trend from January to June in 2019 and 2020. The numbers are presented as a total count and as an index with January of the corresponding year taken as $100 \%$. The Figure suggests that new online job postings in US MSAs collapsed between March and April 2020. They stayed suppressed for two months (April-May) before a partial recovery in June ${ }^{2}$. The trend line was practically the opposite of what was observed in 2019 - labour demand tends to grow in the first half of a year, which was not the case after the virus started spreading in 2020.

During January, February and March 2020, the total number of metropolitan job postings significantly exceeded those in 2019. The difference was largest in January, with almost 900000 more online vacancy announcements in 2020 compared to 2019 (an increase of 36.5\%) ${ }^{3}$. Between March and April 2020, when the effects of the pandemic started to be acutely felt, metropolitan labour demand (as measured by online job ads) contracted by $31.5 \%$ (from 3.3 to 2.2 million job postings in total). The labour demand stayed suppressed in May. Compared to the corresponding months in 2019, the total number of job postings was lower by $20.9 \%$ (April) and $22.6 \%$ (May) despite starting the year at a considerably higher mark. June was

\footnotetext{
${ }^{1}$ In 2019, according to the US Bureau of Labor Statistics, Metropolitan Statistical Areas accounted for $85 \%$ of national employment. $69 \%$ of all workers in the country were employed in MSAs with over 500000 residents and $16 \%$ in small MSAs (under 500000 residents in 2019). More details are provided in Table 2.2.

2 There was another drop in July after the initial recovery in June.

3 This difference likely reflects both an expanding labour market in the US (civilian employment in January 2020 was 2.2 million higher than in January 2019, as reported by the US Bureau of Labour Statistics at https://www.bls.gov/charts/employment-situation/civilian-employment.htm) and an increased use of on-line job announcements for vacancy advertising. The focus of Figure 2.1 however, is on the month-to-month trends rather than on the levels.
} 
the first month of a visible recovery. The number of online vacancy announcements recovered to $84.8 \%$ of its January 2020 value after dropping to $66.5 \%$ in April.

Figure 2.1. Job announcements in US Metropolitan Statistical Areas, first semester 2019 and 2020

Total (millions)

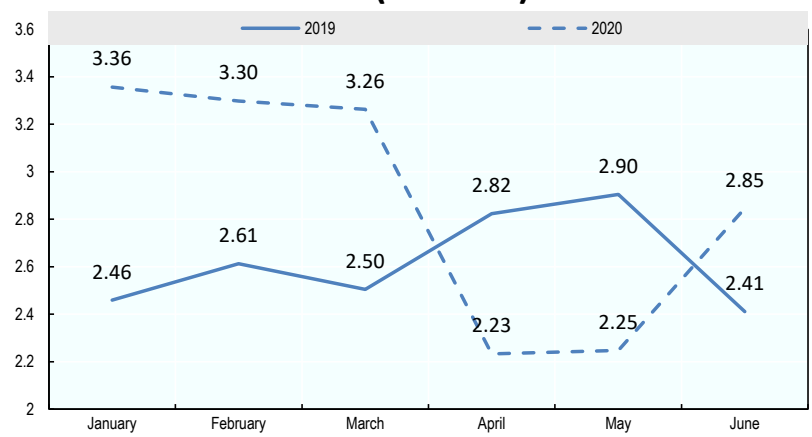

Source: Calculations based on the Burning Glass data (Labor Insight).
Indexed (January=100)

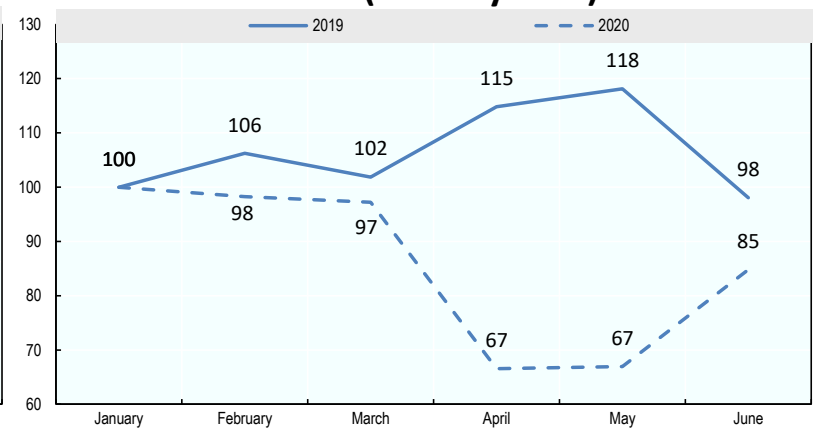

\section{Trends by occupation}

The analysis of job postings by occupation ${ }^{4}$ uses occupational groups defined by the 2010 Standard Occupational Classification (SOC) system developed by the US Bureau of Labor Statistics (BLS). There are 23 occupational groups, which are listed in Box $2.1^{5}$

\footnotetext{
${ }^{4}$ The total number of vacancies by occupation is obtained by summing over all MSAs reported in the Burning Glass data (391 total). The number of vacancies by MSA size is obtained by summing over vacancies in only those MSAs for which population data can be obtained (MSAs defined by the Burning Glass and by US Census Bureau coincide).

${ }^{5}$ Analysis by occupation excludes military occupations. Military occupations are included in total counts described in the National trends subsection.
} 


\section{Box 2.1. List of occupational groups used in the analysis}

\begin{tabular}{r|r|r|r}
\hline \multicolumn{1}{|c|}{ SOC code } & Occupational group & SOC code & Occupational group \\
\hline 11 & Management & 35 & Food Preparation and Serving Related \\
\hline 13 & Business and Financial Operations & 37 & Building and Grounds Cleaning and Maintenance \\
\hline 15 & Computer and Mathematical & 39 & Personal Care and Service \\
\hline 17 & Architecture and Engineering & 41 & Sales and Related \\
\hline 19 & Life, Physical, and Social Science & 43 & Office and Administrative Support \\
\hline 21 & Community and Social Service & 45 & Farming, Fishing, and Forestry \\
\hline 23 & Education, Training, and Library & 49 & Construction and Extraction \\
\hline 25 & Arts, Design, Entertainment, Sports, and Media & 51 & Installation, Maintenance, and Repair \\
\hline 27 & Healthcare Practitioners and Technical & 53 & Production* \\
\hline 29 & Healthcare Support & 55 & Transportation and Material Moving \\
\hline 31 & Protective Service & & Military Specific \\
\hline 33 & & 47 & \\
\hline
\end{tabular}

Note: *The Production occupations (SOC code 51-1000) include a wide range of tasks from those directly related to manufacturing (e. g. Food Processing Workers; Assemblers and Fabricators; Machinists or Textile, Apparel and Furnishings Workers) to occupations likely to be utilised in other industrial sectors (e.g. Nuclear Power Reactor Operators; Water and Wastewater Treatment Plant and System Operators or Medical, Dental and Ophthalmic Laboratory Technicians).

Source: BLS SOC 2010 (https://www.bls.gov/soc/2010/2010_major_groups.htm).

Figure 2.2 shows total new monthly job announcements in MSAs for the most and least affected occupations. The number of online job postings contracted the most in many non-tradable service occupations, particularly those involving face-to-face interactions.

For example, online vacancy postings for Food Preparation and Serving occupations halved between January and April 2020. Other occupations, which in the month of the lowest demand were at less than $60 \%$ compared to January, include Administration and Office Support (52.5\% in April); Arts ( $53.3 \%$ in May); Legal (54.6\% in April); Business Operations (55.6\% in May) and Sales and Related (57.2\% in April). The patterns of a sharp decline and relatively quick recovery was notably consistent for this group of occupations, although the magnitude of the bounce-back differed across occupations. ${ }^{6}$ Labour demand for Food Preparation and Serving was at $91 \%$ of its January level in June but only at $69 \%$ for Business Operations and Arts.

Online job announcements for the least affected occupations declined no lower than $80 \%$ of their January level at the lowest point in April or May. This group of occupations includes Construction; Life, Physical and Social (vacancy postings in both standing at the lowest point of $81.3 \%$ compared to the January level); Building and Maintenance (87.3\% in May) and Transportation and Material Moving (92.8\% in April). Many of these occupations showed relatively strong performance in other months as well, although the patterns are considerably more varied compared to the most affected group of occupations.

\footnotetext{
${ }^{6}$ When considering changes in job postings from January 2020, the differences by definition reflect two major sources of changes, the COVID-19 pandemic and seasonal variation. For most occupations, however, the seasonal pattern is of an increased hiring in the spring months in preparation for the summer season (this is the case, for example, for Food Preparation and Serving). This means that the drop shown in Figure 2.2 is actually smaller than it would have been if seasonal patterns were accounted for (the Figure shows a conservative estimate of the decline).
} 
Figure 2.2. Total job announcements in occupations with largest and smallest decline (January $2020=100$ )
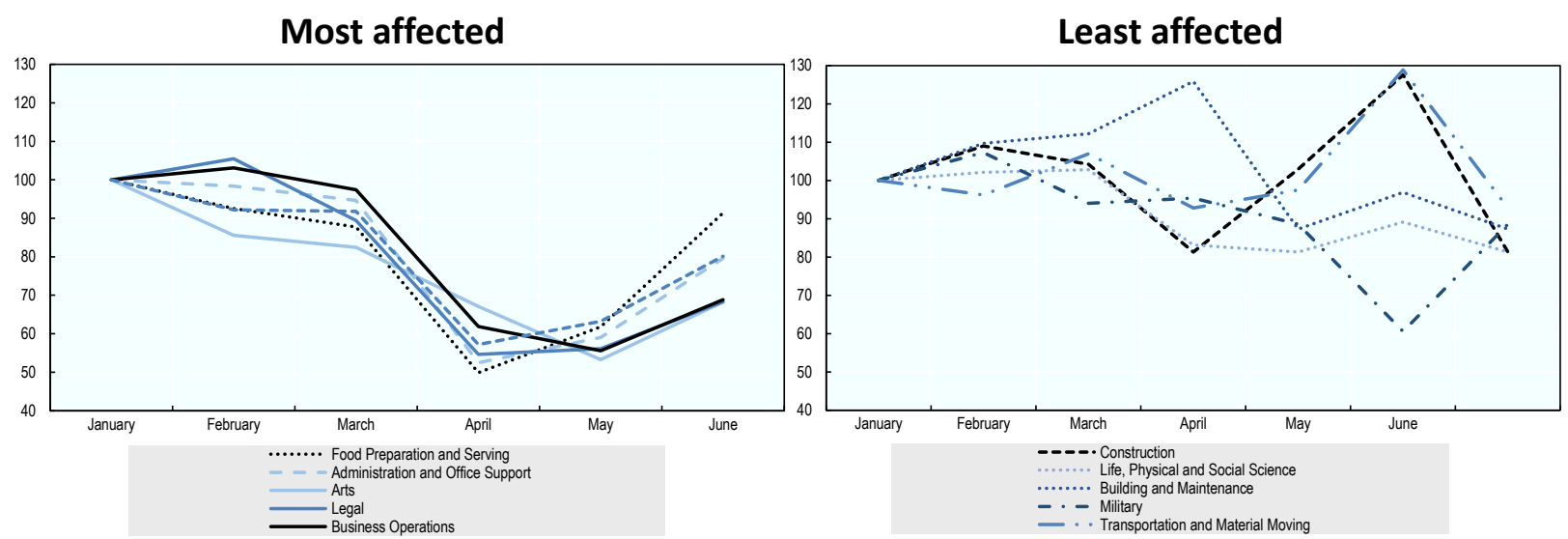

Note: The most (least) affected occupations are the ones with the lowest (highest) value of the index in April or May, whichever is lower (higher). Source: Calculations based on Burning Glass data (Labor Insight).

Figure 2.2 shows the dynamics of labour demand (as advertised online) only for selected occupations. Yet, it clearly demonstrates very unique dynamics for many of them. Different occupations were affected differently not only in terms of the magnitude of the changes but also their timing. While online job postings for some occupations recovered entirely or experienced a strong expansion after a sizable decline, online vacancies for other occupations remained at low levels in June.

Table 2.1 presents a taxonomy of occupational groups by the degree of their decline during the contraction period (April or May, whichever is lower ${ }^{7}$ ) and of recovery afterwards. The Severe (contraction)-Weak (recovery) group includes occupations that were hit hard by the crisis and were slow to recover, at least by the end of June. This group includes such occupations as Arts, Design, Entertainment, Sports and Media; Sales and Related and Legal. The Severe-Strong group includes occupations with a sizable decline but a speedy recovery, for example, Food Preparation and Serving Related or Installation, Maintenance and Repair. Earlier OECD analysis of online job postings by skill group (OECD, 2020[4]) reveals that between February and April, middle-skilled occupations (as opposed to occupations requiring a high and a low level of skills) experienced the largest decline. Table 2.1 is generally in line with this conclusion.

The Mild-Weak group is comprised of occupations in Computer and Mathematical as well as in Architecture and Engineering. These occupations were resilient to the crisis during the first months, at least as evidenced by a relatively small contraction. However, the labour demand of the Mild-Weak group in June was at approximately the same level or slightly lower. Finally, a list of Mild-Strong occupations (those enjoying relatively small contraction followed by a strong growth) includes Life, Physical and Social Science; Transportation and Material Moving and Education, Training and Library ${ }^{8}$.

\footnotetext{
7 Because contraction periods were different for different occupations (e.g. the lowest point for Sales and Related occupations was in April while job postings for Business Operations were at their lowest level in May), the lowest value of the two months (April and May) is used to measure the decline.

8 One needs to keep in mind that the taxonomy was developed using the total counts of online job vacancy announcements for the continental United States. For individual regions, this classification may look very different. A recent presentation by the OECD Spatial Productivity Lab gives some examples of spatial differences in labour demand by occupations within regions (OECD Spatial Productivity Lab, 2020[2]). Because occupational groups shown in Table 2.1 are very broad, classification would also be different for more detailed occupations. For example, while demand for labour within Sports and Arts occupations was likely to contract considerably due to the lockdown orders
} 
Table 2.1. Occupational taxonomy of performance during the contraction and recovery phases

\begin{tabular}{|c|c|c|c|}
\hline Phase & & \multicolumn{2}{|c|}{ Expansion phase (June) } \\
\hline & & Weak (index between 61 and 86) & Strong (index between 89 and 129) \\
\hline \multirow[b]{2}{*}{$\begin{array}{l}\text { Contraction } \\
\text { phase } \\
\text { (April or May) }\end{array}$} & $\begin{array}{r}\text { Severe } \\
\text { (index } \\
\text { between } 50 \\
\text { and } 65 \text { ) }\end{array}$ & $\begin{array}{r}\text { Arts, Design, Entertainment, Sports and Media }(T) \\
\text { Legal }(T) \\
\text { Business and Financial Operations }(T) \\
\text { Management }(T) \\
\text { Office and Administrative Support }(T) \\
\text { Sales and Related }\end{array}$ & $\begin{array}{r}\text { Food Preparation and Serving Related } \\
\text { Healthcare Support } \\
\text { Installation, Maintenance and Repair }\end{array}$ \\
\hline & $\begin{array}{r}\text { Mild } \\
\text { (index } \\
\text { between } 65 \\
\text { and 93) }\end{array}$ & $\begin{array}{r}\text { Computer and Mathematical }(\mathrm{T}) \\
\text { Healthcare Practitioners and Technical } \\
\text { Architecture and Engineering }(\mathrm{T})\end{array}$ & $\begin{array}{r}\text { Life, Physical and Social Science }(\mathrm{T}) \\
\text { Education, Training and Library }(\mathrm{T}) \\
\text { Community and Social Service } \\
\text { Building and Grounds Cleaning and Maintenance } \\
\text { Protective Service } \\
\text { Production } \\
\text { Construction and Extraction } \\
\text { Transportation and Material Moving }\end{array}$ \\
\hline
\end{tabular}

Note: The taxonomy is based on the index (January $=100$ ) of values in April or May (whichever is lower) and June. The list excludes Farming, Fishing and Forestry, which has relatively few job announcements in metropolitan areas and Military Specific occupations. (T) indicates occupations classified as teleworkable, further explained in Section 3. , Box 3.1.

Source: Calculations based on Burning Glass data (Labor Insight).

The table indicates teleworkable occupational groups (further explanations are provided in Section 3. and the list is offered in Box 3.1). Teleworkable occupations tend to be less volatile. They are a part of occupational groups that experienced a severe contraction in labour demand early in the crisis but had relatively slow recovery as well as a part of occupational groups with relatively strong labour demand in the contraction phase, which stayed at the same level or had a strong growth in the recovery period.

In general, changes in labour demand by occupation appear to match relatively well the impact of the COVID-19 pandemic on the labour market. As reported by Gallup, in April and May 2020 service workers were among those most likely to lose a job or to experience loss of income. This is particularly true for food servers and delivery providers, janitors and cleaners among some other occupations. Artists and those in entertainment industry were strongly affected as well. In contrast, STEM (Science, Technology, Engineering and Math), professional and managerial occupations were less affected both in terms of layoffs and the loss of income (Rothwell, 2020[5]).

\section{Trends by Metropolitan Statistical Area size}

Reduction in job postings differed between large and small MSAs. ${ }^{9}$ The contraction was stronger in the large MSAs (population of at least 500 000) with recovery observable only in June. In smaller MSAs, which declined slightly less, increase in online vacancies was observable already in May.

In 2019, larger MSAs outperformed their smaller counterparts in monthly vacancy postings (indexed against January $)^{10}$ during the first six month of the year. The trends for metro areas of both sizes were

and cancellation of many events, Design occupations within the same occupational group could fare better because many jobs related to Design can be performed remotely.

\footnotetext{
${ }^{9}$ Aggregation is done for 364 MSAs identified in the Burning Glass data (100 large and 264 small).

10 The index is calculated by dividing the total number of vacancies across MSAs of same size group (large or small) in a given month by the total number of vacancies for the corresponding group in January of the corresponding year.
} 
generally consistent (Figure 2.3 left panel). In 2020, on the other hand, labour demand weakening during April-June was stronger in MSAs with more than 500000 residents. ${ }^{11}$ It stood at $66.0 \%$ of the January value (a decrease of 34 percentage points) in both April and May (compared to $69.5 \%$ in smaller metro areas in April and $72.9 \%$ in May). Smaller MSAs performed better also in June - online job announcements were at $88.4 \%$ of the January level, while they recovered to only $84.2 \%$ in larger metropolitan statistical areas. $^{12}$

Figure 2.3. Total job announcements in US MSAs by size (January=100), first semester 2019 and 2020

2019

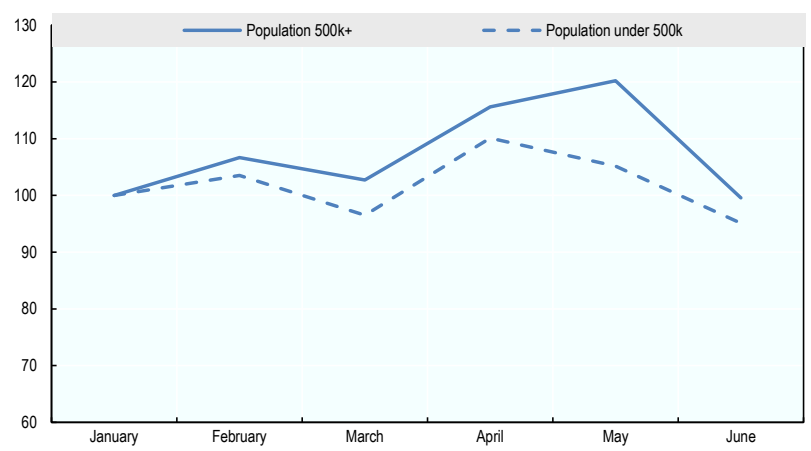

2020

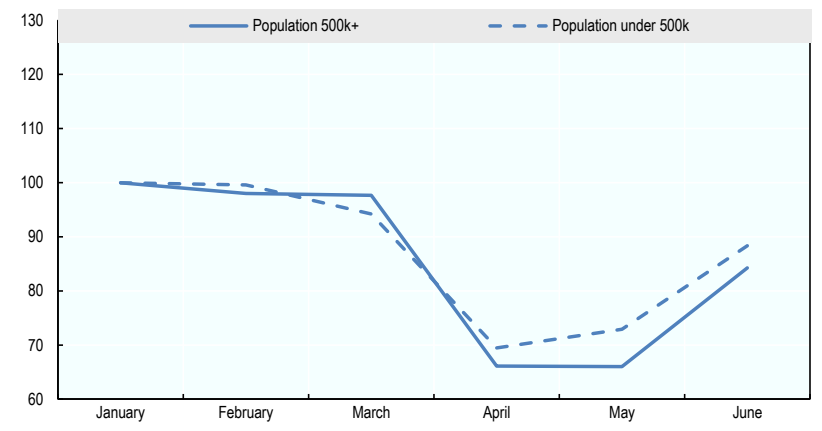

Source: Calculations based on Burning Glass data (Labor Insight).

The weaker performance of the largest metropolitan areas is noteworthy. As $69 \%$ of all US workers are employed in MSAs with more than 500000 residents (and 65\% of the national population lives there), considerably more people were exposed to the negative effects of the strong decline and the slow recovery in the labour markets (as measured by online job postings) of this group of regions.

\section{Table 2.2. Population and employment in US MSAs, 2019}

\begin{tabular}{l|l|l|l|l|l|l}
\hline & $\begin{array}{c}\text { Population } \\
\text { count }\end{array}$ & $\begin{array}{c}\text { Share of } \\
\text { national } \\
\text { population }\end{array}$ & $\begin{array}{c}\text { Share of } \\
\text { metropolitan } \\
\text { population }\end{array}$ & $\begin{array}{c}\text { Employment } \\
\text { count }\end{array}$ & $\begin{array}{c}\text { Share of } \\
\text { national } \\
\text { employment }\end{array}$ & $\begin{array}{c}\text { Share of } \\
\text { metropolitan } \\
\text { employment }\end{array}$ \\
\hline All MSAs & 267922 & $82 \%$ & $100 \%$ & 122311 & $85 \%$ & $100 \%$ \\
\hline Small MSAs & 55848 & $17 \%$ & $21 \%$ & 23191 & $16 \%$ & $19 \%$ \\
\hline Large MSAs & 212074 & $65 \%$ & $79 \%$ & 99120 & $69 \%$ & $81 \%$ \\
\hline
\end{tabular}

Note: Population count and employment count in thousands.

Source: Population data - US Bureau of Census; Employment data - US Bureau of Labour Statistics.

\footnotetext{
${ }^{11}$ The threshold of 500000 residents is a common cut-off value used in US regional research including recent studies that explored the impact of COVID-19 on metropolitan labour markets (Cho, Lee and Winters, 2020[31]).

${ }^{12}$ A more detailed analysis that looks at four groups of MSAs defined by population quartiles (not reported for brevity) suggests that the patterns observed in Figure 2.3 are generally unchanged. During January to June 2019, the largest MSAs (those in the fourth quartile, i.e. with population over 580000 residents) experienced the strongest increase in online job announcements (benchmarked against January 2019) compared to all other size groups. MSAs in the second quartile (population between 145000 and 240 000) had the weakest performance quite closely followed by the smallest metropolitan areas (population under 145000 residents or the first quartile). However, during the first six months of 2020, it was the largest MSAs that suffered the greatest and the most prolonged decline in online vacancy postings. MSAs in all other quartiles, on average, enjoyed smaller contraction. Their expansion started already in May and continued in June, whereas job postings in the largest MSAs still declined in May.
} 


\section{Empirical Analysis}

This section performs an empirical analysis in order to identify regional factors associated with changes in job postings during February - June 2020. The first subsection provides details of the estimation approach and variable calculations. The second subsection presents regression results.

\section{Estimation approach}

\section{Explained Variable: Growth rate benchmarked against expected vacancies}

The analysis aims to identify regional characteristics that are linked to the decrease in job postings in the US MSAs in the first half of 2020. During this time, two separate processes likely affected the dynamics of online vacancies. On the one hand, the COVID-19 pandemic arguably was the main cause of the sharp decline in online job postings in April and in the two subsequent months. On the other hand, several occupations are susceptible to large seasonal variations in hiring rates (e.g., sales associates around Christmas, tourism-related occupations before summer season particularly in popular destinations, etc.).

To account for the distinct effects of these two processes, we calculate growth rates of vacancy announcements benchmarked against the number of vacancies that would be expected at different points of 2020 given the 2019 trends. We calculate the dependent variable for three periods, February-June 2020 (overall period), February-April 2020 (period of the sharpest decline) and May-June 2020 (the period of recovery).

The calculation proceeds in two steps. In the first one, we derive the "2019 factor" as a ratio of the sum of vacancies posted during a period of interest (February-June, February-April or May-June) in 2019 to the total number of vacancies in January 2019. The "factor" accounts for seasonal variation based on the job postings in 2019 and allows for a derivation of the expected vacancies should there be no COVID-19 emergency assuming that seasonal variation in 2020 would have been close to that of 2019. In the next step, we calculate a "growth rate" between the total number of vacancy ads in a period of interest in 2020 and the expected number of vacancies given the January 2020 performance and the "2019 factor". The variable is calculated as shown in Equation 1 at an MSA-occupational group level (362 MSAs and 22 occupations - all listed in Box 2.1 except for Military Specific).

$$
\text { Growt }_{m s a-o c c, t_{2020}}=\frac{\text { job posting } s_{m s a-o c c, t_{2020}}-j o b \text { posting } s_{m s a-o c c, t_{2020}}^{*}}{\text { job posting } s_{m s a-o c c, t_{2020}}^{*}}
$$

where job postings $s_{m s a-o c c, t_{2020}}^{*}=j o b$ posting $s_{m s a-o c c, J a n u a r y 2020} * 2019$ factor $_{t}$ and 2019 factor $_{t}=$ job posting $s_{m s a-o c c, t 2019} /$ job posting $s_{m s a-o c c, J a n u a r y 2019}$; $t$ refers to a time period (February-June, February-April or May-June) and msa-occ denotes an MSA-occupation pair. For the aggregated models, which are estimated at the MSA level, the dependent variable is calculated using the total number of job postings in an MSA (no distinction by occupation) to derive the growth rate and the "2019 factor" (the occ subscript in Equation 1 is dropped). 
Table 3.1 shows summary statistics for the dependent variable at both MSA aggregated and MSAoccupational group levels. On average at the MSA level, the vacancy postings from February to June were $13 \%$ below of what would be expected given the 2019 trends. The total number of vacancies was $14 \%$ lower in February-April and 10\% lower in May-June.

Table 3.1. Summary statistics for the dependent variable

\begin{tabular}{|c|c|c|c|c|c|c|}
\hline Variable & Observations* & Mean & Median & $\begin{array}{l}\text { Standard } \\
\text { deviation }\end{array}$ & Minimum & Maximum \\
\hline & \multicolumn{6}{|l|}{ MSA total } \\
\hline February-June & 362 & -12.52 & -14.96 & 15.28 & -51.89 & 50.21 \\
\hline February-April & 362 & -13.53 & -14.17 & 13.86 & -52.15 & 38.28 \\
\hline \multirow[t]{2}{*}{ May-June } & 362 & -9.89 & -14.32 & 23.19 & -68.80 & 84.04 \\
\hline & \multicolumn{6}{|c|}{ MSA-occupational group } \\
\hline February-June & 7714 & -0.98 & -14.93 & 71.32 & -100 & 1550 \\
\hline February-April & 7714 & -0.35 & -13.48 & 82.25 & -100 & 2150 \\
\hline May-June & 7714 & 6.85 & -16.67 & 115.90 & -100 & 4250 \\
\hline
\end{tabular}

Note: *The number of MSAs used in the empirical analysis is 362 because unemployment data were not available for two of the Metropolitan Statistical Areas included in aggregations in the first section of this paper. There were no vacancies in some occupational groups in some MSAs during the periods used to calculate the dependent variable, which resulted in 7714 MSA-occupation pair observations (instead of 7964 ). Source: Calculations based on Burning Glass data (Labor Insight).

\section{Independent variables: Economic and social regional characteristics}

A wide range of regional social and economic characteristics can determine how a regional economy fares during economic downturns (Martin, 2012[6]; Boschma, 2015[7]). Research on the previous economic shocks offers insights for understanding and predicting regional economic trajectories under adverse economic scenarios. Past research on the Great Recession, for example, has shown that industrial composition (diversity) and the pre-crisis conditions were linked to regional performance (Christopherson, Michie and Tyler, 2010[8] $)$. In particular, recent studies include measures of economic structure (e.g. diversity of employment concentration in specific sectors), agglomeration economies (particularly for metropolitan regions), human capital (education attainment of the population), previous economic performance (e.g. poverty or unemployment rate) and other characteristics (Partridge and Tsvetkova, 2020[9]; Watson and Deller, 2017 $[10]$; Martin et al., 2016[11]).

The ongoing crisis, however, is not like any other in the near past. The new social and economic reality is fundamentally shaped by the spread of COVID-19. In these circumstances, limiting face-to-face contacts becomes the main avenue of fighting the disease, at least until a vaccine or a sufficiently effective treatment is discovered. As a result, new set(s) of regional factors can be relevant for the labour market performance. For instance, teleworking became a new normal for many occupations where performing job duties remotely is feasible (Brynjolfsson et al., 2020 [12]) allowing businesses to continue operations while ensuring workers' safety (Corbetta, forthcoming ${ }_{[13]}$; OECD, 2020 $0_{[4]}$ ). Teleworkable occupations, and industries where such occupations are concentrated, tend to be more resilient during the pandemic. Because of uneven distribution of the 'teleworkable' industries in space, different regions can rely on work from home arrangements to a different degree (Brynjolfsson et al., 2020[12]; OECD, 2020[14]).

US MSAs were hit hard by the coronavirus but its spread was uneven geographically. In response, cities (OECD, 2020[15]) and states implemented a range of policy measures that were aimed at curbing the disease but had direct effects on local economies. The most pertinent ones were restrictions on economic activity introduced at the state and at a city level (the latter were more likely to be directly linked to the actual epidemiological situation in a locality). 
To reflect all these considerations, regional characteristics included in the models approximate five major factors: (1) teleworkability; (2) spread of COVID-19; (3) agglomeration economies; (4) economic structure and previous economic performance; (5) human capital. The links are estimated after removing the influence of the time-invariant traits within each state (to account for differences in tax and business environment but also, and more importantly, for variations in lockdown regimes). Table 3.2 lists all variables, gives their brief description, source(s) of data and years. More detailed explanations are provided next.

\section{Table 3.2. Description of independent variables}

\begin{tabular}{|c|c|c|c|c|}
\hline Group & Regional characteristic & Description and unit & Source & Year \\
\hline Teleworkability (Tele) & Teleworkability & $\begin{array}{r}\text { Share of employment in occupations } \\
\text { that are classified as feasible to } \\
\text { perform remotely, } \%\end{array}$ & $\begin{array}{r}\text { Dingel and Neiman } \\
\left(2020_{[16]}\right)\end{array}$ & 2018 \\
\hline COVID-19 (COVID) & COVID-19 contagion & $\begin{array}{r}\text { Daily average number of cases per } \\
10000 \text { residents }\end{array}$ & USA Facts & 2020 \\
\hline $\begin{array}{r}\text { Agglomeration economies } \\
(\text { Agglom })\end{array}$ & Population density & $\begin{array}{r}\text { Population per land area (square } \\
\text { mile), thousand people }\end{array}$ & US Census Bureau & 2019 \\
\hline \multirow{5}{*}{$\begin{array}{r}\text { Local economic structure and } \\
\text { previous economic } \\
\text { performance (Economy) }\end{array}$} & Population growth & $\begin{array}{r}\text { Growth rate in total MSA population, } \\
\%\end{array}$ & US Census Bureau & $\begin{array}{r}2013- \\
2018\end{array}$ \\
\hline & Wage growth & $\begin{array}{r}\text { Growth in average wage (inflation } \\
\text { adjusted), \% }\end{array}$ & $\begin{array}{r}\text { US Bureau of } \\
\text { Economic Analysis }\end{array}$ & 2018 \\
\hline & Unemployment & Unemployment rate, \% & $\begin{array}{r}\text { US Bureau of Labour } \\
\text { Statistics }\end{array}$ & 2019 \\
\hline & Related variety & $\begin{array}{r}\text { Variety (shares of employment in } \\
\text { individual industries) within major } \\
\text { industrial sectors }\end{array}$ & $\begin{array}{r}\text { W.E. Upjohn Institute } \\
\text { of Employment } \\
\text { Research }\end{array}$ & 2016 \\
\hline & Unrelated variety & $\begin{array}{l}\text { Variety (shares of employment) } \\
\text { across major industrial sectors }\end{array}$ & $\begin{array}{r}\text { W.E. Upjohn Institute } \\
\text { of Employment } \\
\text { Research }\end{array}$ & 2016 \\
\hline Human capital (HumCap) & Education & $\begin{array}{r}\text { Share of adults with Bachelor degree } \\
\text { or higher, } \%\end{array}$ & US Census Bureau & 2018 \\
\hline
\end{tabular}

Note: Italicised abbreviations in parentheses in the first column are the ones used to denote the (groups of) variables in the estimation equations below.

Teleworking became the new normal for many people during the pandemic. As social distancing was required to slow down the spread of COVID-19, remote work emerged as a necessary condition for continued operations for many firms. The ability to switch to teleworking, however, to a large degree was determined by prior experience with teleworking, in addition to the nature of business operations and other factors $\left(O E C D, 2020_{[17]}\right)$. The use of remote work before the crisis varied considerably across types of jobs, industries, occupations and places (OECD, 2020[14]; European Commission, 2020[18]). This implies that variation in prior exposure to teleworking but also the degree of 'teleworkability' in a region can plausibly affect labour demand.

There are at least two mechanisms that link 'teleworkability' and labour demand that could be potentially at work. On the one hand, teleworkable jobs are less likely to be shed. This, together with generally slowing down economic activity, can have a negative effect on labour demand as there are no new vacancies to be (re)filled. On the other hand, more teleworkable jobs, which tend to pay higher wages (Brussevich, Dable-Norris and Khalid, 2020[19]), are likely to contribute to local demand for goods and services potentially supporting labour demand indirectly.

This paper uses a measure of teleworkability at MSA level developed by Dingel and Neiman (2020[16]). The authors classify occupations by the feasibility of remote work based on surveys of worker experience. Using 2018 employment data, Dingel and Neiman estimate the share of jobs in a metropolitan area that do not require personal presence. 
Another distinctive feature of the ongoing crisis is the unequal geographically and time-varying spread of the COVID-19 virus. Localities with high incidence of cases were more likely to limit economic activity as a result of both administrative restrictions and people not able (or not willing due to the risk of contagion) to continue working. In many circumstances, the likelihood of virus spread was determined by the nature of professional activities and the extent of personal interactions required for a specific occupation (OECD, $\left.2020_{[4]}\right)$. To account for differences in the prevalence of the disease across MSAs, this paper uses population-adjusted average daily number of cases as a control, obtained from USA Facts. ${ }^{13}$ The variable is aggregated from county level data for the three periods used in estimation, February-June, FebruaryApril and May-June.

Agglomeration economies are concentrations of economic activity and people, which boost productivity performance of firms located within them (Duranton and Kerr, 2015[20]). During the COVID-19 pandemics, agglomerated regions could enjoy better labour market outcomes due to higher demand, greater ability to adjust to the new reality as a result of knowledge spillovers, better labour matching, enhanced infrastructure, availability of diverse business services and other factors. At the same time, the concentration of people could propel the spread of the virus suppressing economic activity in general and labour demand in particular. The extent of agglomeration economies in this paper is measured by the number of residents (in thousands) per square mile of land area. Estimates of both population and metropolitan land area are provided by the US Census Bureau.

Economic performance before the crisis as well as economic structure are often related to the economic dynamics during the times of hardship. Flourishing regions are more likely to weather an economic downturn compared their counterparts that struggled during the times of stability and growth. This paper uses three measures of pre-crisis economic conditions. Population growth reflects expanding size of the local market, which is likely to translate into increased economic activity and potentially higher demand for labour. Average wage growth indicates that a regional economy increases production of higher valueadded goods and services. Such transformation would usually require higher levels of technology, human capital or both. The growth rates included in the models (population and average wages) refer to the 20132018 period and are obtained from the US Census Bureau and the US Bureau of Economic Analysis, respectively. Finally, the models include the 2018 unemployment rate (provided by the US Bureau of Labour Statistics) as a measure of economic hardship.

Likewise, economic structure can affect economic performance at the regional level via multiple mechanisms. For example, industrial diversity can offer hedging effects or create conditions for knowledge sharing and recombination. The so-called related diversity (variety of individual industries within broader industrial sectors), is linked to new development paths, knowledge spillovers and economic renewal. ${ }^{14}$ Greater related diversity might allow for greater levels of flexibility where resources can be reallocated within a regional economy more easily due to different, but still not too distant in terms of technological and skills, contents. Recent research shows that such flexibility, or a 'rewiring' ability, was associated after the Great Recession with higher employment growth, particularly in less vibrant places (Partridge and Tsvetkova, 2020[9]). On the other hand, closer linkages through a denser 'industrial fabric' can potentially offer additional paths for an economic shock to proliferate through the economy. Besides, higher industrial variety within major sectors indicates greater specialisation of labour and increased supply of highly specialised and niche goods and services, which are likely to be shed first when demand collapses because of multiple simultaneous shocks to the economy.

\footnotetext{
13 https://usafacts.org/.

${ }^{14}$ http://relatedvariety.s3platform.eu/\#: :text=About,Related\%20variety\%20is\&text=Related\%20variety\%20is\%20estimated\%20using,employment $\% 20$ across\%202\%2D digit\%20classes.
} 
Unrelated diversity, on the other hand, refers to the variety of industries, which are very distinct in their technological/skills content or knowledge base. Regions enjoying a high level of unrelated variety are likely to benefit from a portfolio effect. In other words, if a crisis heavily affects some industries or occupations, they account for a smaller share of the overall economy in a diversified region (Deller and Watson, 2016 [21]; Boschma, 2015 $[7]$; Cainelli, Ganau and Modica, 2019 $\left.{ }_{[22]}\right)$. This is expected to be the case if shocks hit individual industries or sectors. The hedging effect becomes less relevant in a broad-based crisis where abrupt contraction of economic activity comes from both demand and supply sides.

The equations estimated in this paper include a measure of related variety (calculated at the North American Industrial Classification System 4-digit level) and a measure of unrelated variety (calculated at the 2-digit level) following Frenken, van Oort and Verburg (2007[23]). The US Bureau of Labour Statistics is the source for the employment-by-industry data used in calculations. Because the original data source suppresses employment counts by industry for many smaller regions due to confidentiality concerns, the paper uses a variant of the data provided by the W.E. Upjohn Institute of Employment Research (Bartik et al., 2018[24]). The Institute uses linear programming algorithm developed by Isserman and Westervelt $\left(2006_{[25]}\right)$ to fill in the suppressed values. ${ }^{15}$ The estimation uses 2016 data as the last available year.

Finally, human capital is one of the main components of economic performance of a region. Higher levels of human capital are generally associated with greater innovation, absorptive capacity and resilience (Gennaioli et al., 2013[26]; Glaeser, Ponzetto and Tobio, 2014[27]). The link between human capital and economic fortunes of a locality appears to be stronger in cities (Glaeser and Resseger, 2010[28]; Glaeser and Maré, $2001_{[29]}$ ). The paper uses the 2018 share of adult population with a college degree (a Bachelor degree or higher) as a measure of human capital. The US Census Bureau is the data source.

In addition to the described regional characteristics, all models include state fixed effects, which account for time-invariant characteristics of individual states such as differences in the lockdown regimes and other factors. MSAs that span more than one state were assigned to the state where the largest share of the population lives. Table 3.3 shows descriptive statistics for the independent variables.

Table 3.3. Summary statistics for the independent variables

\begin{tabular}{r|r|r|r|r|r}
\hline \multicolumn{1}{|c|}{ Variable } & \multicolumn{1}{|c|}{ Mean } & \multicolumn{1}{c|}{ Median } & Standard Deviation & \multicolumn{1}{c}{ Minimum } & Maximum \\
\hline Teleworkability & 32.34 & 31.30 & 5.48 & 19.27 & 51.89 \\
\hline COVID-19, February-June 2020 & 16.04 & 10.78 & 16.63 & 1.06 & 124.00 \\
\hline COVID-19, February-April 2020 & 3.30 & 2.12 & 4.56 & 0.24 & 47.42 \\
\hline COVID-19 May-June 2020 & 34.84 & 23.29 & 35.99 & 2.08 & 287.73 \\
\hline Population density & 276.12 & 182.96 & 310.47 & 7.71 & 2725.57 \\
\hline Population growth & 3.23 & 2.73 & 4.57 & -6.81 & 20.41 \\
\hline Wage growth & 4.44 & 4.60 & 4.12 & -13.08 & 25.33 \\
\hline Unemployment & 3.92 & 3.70 & 1.48 & 1.90 & 18.30 \\
\hline Related variety & 56.12 & 55.99 & 5.39 & 37.72 & 68.61 \\
\hline Unrelated variety & 3.53 & 3.54 & 0.17 & 2.58 & 3.88 \\
\hline Education & 29.81 & 28.35 & 10.93 & 8.30 & 65.30 \\
\hline
\end{tabular}

Note: Number of observation is 362 .

Source: Sources for each variable are listed in Table 3.2.

15 The algorithm is, in a sense, a massive system of equations, in which suppressed values are the unknowns, estimated subject to the condition that the sum of rows and columns by county and industry sum up to the national and state totals (including by industry and sector), which are not suppressed. 


\section{Estimation}

Several econometric specifications are estimated in this paper. The base one (Equation 2) is estimated using MSA-level (aggregate) data.

$$
\begin{gathered}
\text { Growth }_{m s a, t_{2020}}=\beta_{0}+\beta_{1} \text { Tele }_{m s a, 2018}+\beta_{2} \text { COVID }_{m s a, t 2020}+\beta_{3} \text { Agglom }_{m s a, 2019}+ \\
\beta_{4} \text { Economy }_{m s a, 2016 / 2018 / 2019}+\beta_{5} \text { HumCap }_{m s a, 2018}+\theta_{s}+\varepsilon_{m s a, t 2020},
\end{gathered}
$$

where subscript $m s a$ indicates one of 362 MSAs and $t$ is the time period under consideration in line with the dependent variable calculation (February-June, February-April or May-June). The derived estimates show the correlation between labour market performance and a range of regional characteristics keeping other variables constant. ${ }^{16}$ State level effects, such as differentiated lockdown policies and progressive exist from the lockdown, are captured by $\theta_{s}$, which is a fixed effect for each state.

The broad adoption of the social distancing requirements and introduction of teleworking can lead to dissimilar demand for jobs that can and cannot be performed remotely. To test for such a possibility, we use an alternative specification (Equation 3). The specification is different from Equation 2 in two ways. First, the dependent variable is calculated at the MSA-occupation level. Second, three independent variables are interacted with an indicator of occupational teleworkability.

$$
\begin{aligned}
\text { Growth }_{m s a-o c c, t_{2020}} & \\
& =\beta_{0}+\beta_{1} \text { Tele }_{m s a, 2018}+\beta_{2} \text { COVID }_{m s a, t 2020}+\beta_{3} \text { Agglom }_{m s a, 2019} \\
& \times \text { Teleworkability }_{\text {occ }}+\beta_{4} \text { PopGrowth }_{m s a, 2013-2018} \\
& \times \text { Teleworkability }_{\text {occ }}+\beta_{5} \text { WageGrowth }_{m s a, 2013-2018} \\
& \times \text { Teleworkability }_{\text {occ }}+\beta_{6} \text { Unemployment }_{m s a, 2019} \\
& +\beta_{7} \text { RelatedVariery }_{m s a, 2016}+\beta_{8} \text { UnrelatedVariery }_{m s a, 2016} \\
& +\beta_{9} \text { HumCap }_{m s a, 2018}+\theta_{s}+\varepsilon_{m s a-o c c, t_{2020}}
\end{aligned}
$$

where subscript occ refers to one of 22 occupational groups used in the analysis and Teleworkability occ is an indicator variable, which takes on the value of one if an occupational group is classified as teleworkable following the procedure described in Box 3.1.

\footnotetext{
${ }^{16} \mathrm{It}$ is important to remember that the derived estimates indicate statistically significant correlation, not causation. The research design of this study does not allow for assessing causal relationships. While all independent variables are exogenous to the COVID-19 crisis and pre-date job announcement variation, we cannot exclude the possibility that there are omitted variables that affect both the independent variables and the response of job growth during the months of the crisis.
} 


\section{Box 3.1. Teleworkability of occupations}

An occupational group is identified as teleworkable if more than $50 \%$ of 2018 employment within this occupational group was in occupations that Dingel and Neiman $\left(2020_{[16]}\right)$ classify as teleworkable. To transform their teleworkability measure calculated at the 8-digit SOC into the 6-digit one for which employment data are available, the mean of teleworkability index is calculated within each 6-digit SOC code and an occupation is considered teleworkable if the mean is greater than 0.5. Table 3.4 lists the occupations that are designated as teleworkable.

\section{Table 3.4. Teleworkable occupations at 2-digit SOC code}

\begin{tabular}{|c|c|c|c|}
\hline SOC code & Occupational group & SOC code & Occupational group \\
\hline 11 & Management & 23 & Legal \\
\hline 13 & Business and Financial Operations & 25 & Education, Training, and Library \\
\hline 15 & Computer and Mathematical & 27 & $\begin{array}{r}\text { Arts, Design, Entertainment, Sports, and } \\
\text { Media }\end{array}$ \\
\hline 17 & Architecture and Engineering & 43 & Office and Administrative Support \\
\hline 19 & Life, Physical, and Social Science & & \\
\hline
\end{tabular}

Source: Calculations based on (Dingel and Neiman, 2020[16] $)$ and May 2018 employment by occupation data from the US Bureau of Labor Statistics (https://www.bls.gov/oes/tables.htm).

\section{Regression results}

Table 3.5 shows estimation results for all MSAs for the whole period (February-June), the contraction phase (February-April) and the recovery phase (May-June). The table suggests that places with greater share of teleworkable employment in 2018 tended to experience less labour market weakening keeping other factors constant. On average, in MSAs with an additional $1 \%$ of teleworkable jobs (as a share of total employment in 2018), the number of online job ads was $0.9 \%$ higher than what would be expected given the 2019 trends. In contrast, MSAs with higher unemployment rates pre-crisis performed worse. More educated metropolitan areas also tended to suffer deeper declines in labour demand. This could be linked to the fact that larger metropolitan areas, which usually are more educated, were hit harder and earlier in the crisis. ${ }^{17}$

Another observation that follows from Table 3.5 is that in the recovery phase (May-June), labour market demand appears correlated with more regional characteristics. For example, labour demand in May-June was stronger in faster-growing MSAs (using 2013-2018 growth rates). In contrast, MSAs with more diverse industrial structure within major industrial sectors tended to perform worse in terms of online job announcements. This sets the ongoing crisis apart from the previous global downturns of economic activity when industrial diversity contributed to regional economic resilience in the US (Brown and Greenbaum, 2017[30]; Deller and Watson, 2016[21]). The very different nature of the crisis (emanating from a healthcare emergency coupled with the efforts to curb the spread of the virus via severe restrictions on economic and social life) could be one of the explanations for the observed association. Related variety is also linked to

\footnotetext{
17 There is a positive correlation between educational attainment and teleworkability. Estimation results in this paper suggest that for a given level of education in an MSA, areas with more teleworkable jobs tended to have a smaller decline (or larger growth) in labour demand.
} 
an enhanced offer of more specialised goods and services, demand for which is likely to fall during economic downturns.

Finally, the spread of COVID-19 does not appear to be linked to growth in job postings. Although the estimation coefficient is always negative, it is statistically insignificant. Previous research has found a negative relationship between prevalence of the disease and employment status in US MSAs at the individual worker level (Cho, Lee and Winters, 2020[31]). Results presented here point to the differences in the underlying factors for employment status and online labour demand (job postings). Most likely, the decision to open a vacancy is affected more by the regulatory regime in a place (if a business is able to continue operations) than by the concerns about COVID-19 cases. In regression estimation, effects of a regulatory regime are factored out by state dummy. The ability to work, on the other hand, is likely to be affected by the health status of a worker, her willingness and ability to continue working (e.g. some caregivers had to choose between a job and providing care for family members) and by the mode of operation adopted by her employer.

\section{Table 3.5. Estimation results, MSA aggregated}

Dependent variable: growth rate in number of vacancies benchmarked against expectations based on 2019

\begin{tabular}{|c|c|c|c|}
\hline Regional characteristics & February-June & February-Apr & May-June \\
\hline \multirow[t]{2}{*}{ Teleworkability (employment share), 2018} & $0.918^{* * *}$ & $0.870^{* * *}$ & $0.979^{* *}$ \\
\hline & $(0.270)$ & $(0.226)$ & $(0.467)$ \\
\hline \multirow[t]{2}{*}{ COVID-19, 2020} & -0.075 & -0.224 & -0.045 \\
\hline & $(0.059)$ & $(0.186)$ & $(0.044)$ \\
\hline \multirow[t]{2}{*}{ Population density, 2019} & 0.005 & 0.004 & 0.007 \\
\hline & $(0.004)$ & $(0.003)$ & $(0.005)$ \\
\hline \multirow[t]{2}{*}{ Population growth, 2013-18 } & $0.759^{*}$ & 0.469 & $1.246^{* *}$ \\
\hline & $(0.391)$ & $(0.352)$ & $(0.562)$ \\
\hline \multirow[t]{2}{*}{ Average wage growth, 2013-18 } & -0.071 & -0.003 & -0.215 \\
\hline & $(0.219)$ & $(0.183)$ & $(0.358)$ \\
\hline \multirow[t]{2}{*}{ Unemployment, 2019} & $-1.688^{* * *}$ & $-1.625^{\star \star *}$ & $-2.063^{* * *}$ \\
\hline & $(0.394)$ & $(0.412)$ & $(0.561)$ \\
\hline \multirow[t]{2}{*}{ Related (intrasectoral) variety, 2016} & $-0.904^{* * *}$ & $-0.589^{*}$ & $-1.436^{* * *}$ \\
\hline & $(0.321)$ & $(0.329)$ & $(0.407)$ \\
\hline \multirow[t]{2}{*}{ Unrelated (intersectoral) variety, 2016} & -0.657 & 4.459 & -10.122 \\
\hline & (7.599) & $(6.696)$ & $(10.994)$ \\
\hline \multirow[t]{2}{*}{ Human capital, 2018} & $-0.595^{* * *}$ & $-0.385^{* * *}$ & $-0.944^{* * *}$ \\
\hline & $(0.109)$ & $(0.122)$ & $(0.202)$ \\
\hline \multirow[t]{2}{*}{ Constant } & $36.152^{* *}$ & -1.235 & $104.595^{\star * *}$ \\
\hline & (15.857) & (13.862) & (23.601) \\
\hline R-squared & 0.346 & 0.336 & 0.361 \\
\hline
\end{tabular}

Note: ${ }^{* * *}$ - significant at the 0.01 level; ${ }^{* *}$ - significant at the 0.05 level; ${ }^{*}$ - significant at the 0.1 level. Standard errors clustered at state level (MSAs spanning more than one state are assigned to the state with highest share of total MSA population) are given in parentheses. The models include state fixed effects. Number of observations: 362.

To limit the influence of outliers (very large positive values of the dependent variable), in addition to the whole sample, estimation is performed using observations with values of the dependent variable below 1000 and below 500 . Table 3.6 shows estimation results.

Estimation results stay generally the same for all explanatory variables, which are not interacted with a teleworkability indicator. The only difference worth noting is that statistical significance of the share of teleworkable employment decreases in several models displayed in Table 3.6. In the preferred model (with 
the most restricted sample, which limits the influence of outliers), the share of teleworkable employment is statistically related to relatively more online vacancies during the overall period (February-June) and in the expansion phase (May-June). ${ }^{18}$

The analysis also uncovers differences in labour demand for teleworkable and nonteleworkable occupations. ${ }^{19}$ The results for the preferred sample suggest labour demand for nonteleworkable occupations was recovering faster in more dense MSAs, which was likely related to greater local demand for goods and services. Labour demand for both teleworkable and nonteleworkable occupations was growing more (or contracting less) in more attractive metropolitan areas (those with higher population growth in 2013-2018). In contrast, demand for teleworkable occupations, which tend to be better-paid and to require higher educational levels, stayed relatively low in cities with higher pre-crisis wage growth. This can potentially signal (if the uncovered link is not a short-lived phenomenon but something characterising metropolitan labour demand during longer period of the pandemic and beyond) an opportunity for less expensive places, such as smaller cities and rural areas, to attract teleworkable jobs.

\section{Table 3.6. Estimation results, MSA-occupation pairs}

Dependent variable: growth rate in number of vacancies benchmarked against expectations based on 2019

\begin{tabular}{|c|c|c|c|c|c|c|c|c|c|}
\hline \multirow[t]{2}{*}{$\begin{array}{c}\text { Regional } \\
\text { characteristics }\end{array}$} & $\begin{array}{l}\text { February- } \\
\text { June }\end{array}$ & $\begin{array}{l}\text { February - } \\
\text { April }\end{array}$ & May -June & $\begin{array}{l}\text { February- } \\
\text { June }\end{array}$ & $\begin{array}{c}\text { February - } \\
\text { April }\end{array}$ & $\begin{array}{l}\text { May - } \\
\text { June }\end{array}$ & February- June & $\begin{array}{l}\text { February - } \\
\text { April }\end{array}$ & $\begin{array}{l}\text { May - } \\
\text { June }\end{array}$ \\
\hline & \multicolumn{3}{|c|}{ Full sample } & \multicolumn{3}{|c|}{ Dependent variable $<1000$} & \multicolumn{3}{|c|}{ Dependent variable $<500$} \\
\hline \multirow{2}{*}{$\begin{array}{l}\text { MSA teleworkability } \\
\text { (employment share) }\end{array}$} & $0.901^{* *}$ & $0.654^{*}$ & $1.255^{\star}$ & $0.730^{*}$ & $0.703^{*}$ & $1.155^{*}$ & $0.788^{\star \star}$ & $0.637^{\star}$ & $1.002^{* *}$ \\
\hline & $(0.417)$ & $(0.373)$ & $(0.717)$ & $(0.398)$ & $(0.354)$ & $(0.604)$ & $(0.318)$ & $(0.326)$ & $(0.481)$ \\
\hline \multirow[t]{2}{*}{ COVID-19 } & -0.080 & -0.221 & -0.092 & -0.072 & -0.225 & -0.050 & -0.059 & -0.298 & -0.041 \\
\hline & $(0.092)$ & $(0.330)$ & $(0.066)$ & $(0.089)$ & $(0.298)$ & $(0.058)$ & $(0.079)$ & $(0.257)$ & $(0.054)$ \\
\hline \multicolumn{10}{|l|}{$\begin{array}{r}\text { Population density } \\
\text { on: }\end{array}$} \\
\hline \multirow[t]{2}{*}{ Nonteleworkable } & $0.008^{*}$ & 0.004 & $0.020^{* * *}$ & $0.008^{\star *}$ & 0.002 & $0.016^{* * *}$ & $0.008^{\star \star}$ & 0.004 & $0.017^{* * *}$ \\
\hline & $(0.004)$ & $(0.005)$ & $(0.006)$ & $(0.004)$ & $(0.004)$ & $(0.005)$ & $(0.003)$ & $(0.003)$ & $(0.005)$ \\
\hline \multirow[t]{2}{*}{ Teleworkable } & 0.001 & 0.002 & 0.004 & -0.000 & 0.001 & -0.004 & 0.001 & 0.003 & -0.001 \\
\hline & $(0.005)$ & $(0.005)$ & $(0.008)$ & $(0.005)$ & $(0.004)$ & $(0.006)$ & $(0.004)$ & $(0.004)$ & $(0.005)$ \\
\hline \multicolumn{10}{|l|}{$\begin{array}{r}\text { Population growth } \\
\text { on: }\end{array}$} \\
\hline \multirow[t]{2}{*}{ Nonteleworkable } & 0.659 & 0.078 & $2.465^{\star *}$ & 0.619 & 0.165 & $1.293^{*}$ & 0.843 & 0.338 & $1.507^{* *}$ \\
\hline & $(0.548)$ & $(0.534)$ & $(1.222)$ & $(0.555)$ & $(0.423)$ & $(0.705)$ & $(0.530)$ & $(0.389)$ & $(0.580)$ \\
\hline \multirow[t]{2}{*}{ Teleworkable } & 0.854 & 0.733 & $1.847^{*}$ & 0.760 & 0.389 & $1.286^{*}$ & 0.473 & 0.135 & $1.394^{* *}$ \\
\hline & $(0.592)$ & $(0.768)$ & $(1.026)$ & $(0.595)$ & $(0.478)$ & $(0.763)$ & $(0.594)$ & $(0.307)$ & $(0.651)$ \\
\hline \multicolumn{10}{|l|}{ Wage growth on: } \\
\hline \multirow[t]{2}{*}{ Nonteleworkable } & -0.055 & 0.061 & -0.326 & -0.089 & 0.102 & -0.373 & 0.004 & 0.066 & 0.107 \\
\hline & $(0.407)$ & $(0.357)$ & $(0.600)$ & $(0.420)$ & $(0.364)$ & $(0.537)$ & $(0.312)$ & $(0.330)$ & $(0.433)$ \\
\hline \multirow[t]{2}{*}{ Teleworkable } & $-0.637^{*}$ & -0.046 & $-1.370^{\star *}$ & -0.535 & -0.002 & $-1.464^{* *}$ & -0.227 & 0.066 & $-1.159^{* *}$ \\
\hline & $(0.361)$ & $(0.457)$ & $(0.642)$ & $(0.367)$ & $(0.417)$ & $(0.637)$ & $(0.315)$ & $(0.326)$ & $(0.462)$ \\
\hline
\end{tabular}

18 In the models that use percent growth (January-June, January-April and April-June mid-point formula to mitigate the influence of outliers) as the dependent variable, the result for the whole period is identical to the one reported in Table 3.6 both in terms of the magnitude and the significance level. Estimation coefficient for the expansion phase is statistically insignificant but it is significant at the .99 level for the contraction phase with the coefficient of 0.71 .

19 Separate estimation for the teleworkable and nonteleworkable occupations is reported inAnnex A. Generally, the results suggest that job posting for teleworkable occupations were higher in MSAs with larger share of jobs that can be performed remotely during the whole period (February-June) and during the contraction phase (February-April). During the expansion phase (May-June), in contrast, job postings were higher for nonteleworkable occupations in MSAs with higher share of jobs that can be performed remotely. 


\begin{tabular}{|c|c|c|c|c|c|c|c|c|c|}
\hline \multirow[t]{2}{*}{$\begin{array}{c}\text { Regional } \\
\text { characteristics }\end{array}$} & $\begin{array}{l}\text { February- } \\
\text { June }\end{array}$ & $\begin{array}{l}\text { February - } \\
\text { April }\end{array}$ & May -June & $\begin{array}{l}\text { February- } \\
\text { June }\end{array}$ & $\begin{array}{c}\text { February - } \\
\text { April }\end{array}$ & $\begin{array}{l}\text { May - } \\
\text { June }\end{array}$ & February- June & $\begin{array}{c}\text { February - } \\
\text { April }\end{array}$ & $\begin{array}{l}\text { May - } \\
\text { June }\end{array}$ \\
\hline & \multicolumn{3}{|c|}{ Full sample } & \multicolumn{3}{|c|}{ Dependent variable $<1000$} & \multicolumn{3}{|c|}{ Dependent variable $<500$} \\
\hline \multirow{2}{*}{$\begin{array}{c}\text { Unemployment } \\
\text { rate }\end{array}$} & $-2.547^{\star \star \star}$ & $-2.583^{\star \star \star}$ & $-2.817^{\star *}$ & $-2.715^{\star \star *}$ & $-2.317^{* * *}$ & $-2.895^{\star * *}$ & $-2.078^{\star * *}$ & $-2.160^{* * *}$ & $-2.498^{* * *}$ \\
\hline & $(0.714)$ & $(0.693)$ & $(1.186)$ & $(0.772)$ & $(0.608)$ & $(1.028)$ & $(0.671)$ & $(0.515)$ & $(0.908)$ \\
\hline \multirow[t]{2}{*}{ Related variety } & -9.619 & 0.553 & -18.387 & -9.684 & -0.446 & -22.171 & -6.244 & 1.867 & -16.926 \\
\hline & (11.929) & (12.818) & $(19.803)$ & $(11.129)$ & $(11.867)$ & (13.404) & $(9.971)$ & $(10.404)$ & (12.250) \\
\hline \multirow[t]{2}{*}{ Unrelated variety } & $-1.973^{* \star *}$ & $-1.762^{\star \star \star}$ & $-3.533^{* * *}$ & $-1.741^{* * *}$ & $-1.515^{\star * *}$ & $-2.601^{* * *}$ & $-1.590^{* * *}$ & $-1.284^{* * *}$ & $-2.218^{* * *}$ \\
\hline & $(0.421)$ & $(0.467)$ & $(0.837)$ & $(0.371)$ & $(0.356)$ & $(0.469)$ & $(0.369)$ & $(0.325)$ & $(0.456)$ \\
\hline \multirow[t]{2}{*}{ Human capital } & $-0.813^{\star \star *}$ & $-0.634^{\star \star *}$ & $-1.473^{\star * \star}$ & $-0.780^{\star \star \star}$ & $-0.554^{\star \star \star}$ & $-1.108^{\star \star *}$ & $-0.681^{* \star *}$ & $-0.433^{\star * *}$ & $-1.047^{\star * *}$ \\
\hline & $(0.161)$ & $(0.192)$ & $(0.346)$ & $(0.151)$ & $(0.172)$ & $(0.292)$ & $(0.126)$ & $(0.140)$ & $(0.202)$ \\
\hline \multirow[t]{2}{*}{ Constant } & $145.764^{\star * *}$ & $105.859^{\star \star *}$ & $271.343^{\star \star *}$ & $138.670^{\star \star \star}$ & $89.554^{\star \star *}$ & $223.214^{* * *}$ & $109.233^{* * *}$ & $65.956^{\star \star \star}$ & $184.330^{\star * *}$ \\
\hline & (23.301) & $(25.079)$ & $(35.113)$ & $(21.814)$ & $(24.723)$ & (31.428) & (18.806) & (20.777) & (25.276) \\
\hline R-squared & 0.041 & 0.028 & 0.050 & 0.043 & 0.029 & 0.064 & 0.048 & 0.032 & 0.080 \\
\hline Observations & 7714 & 7714 & 7714 & 7711 & 7707 & 7700 & 7686 & 7684 & 7651 \\
\hline
\end{tabular}

Note: ${ }^{* * *}$ - significant at the 0.01 level; ${ }^{* *}$ - significant at the 0.05 level; ${ }^{*}$ - significant at the 0.1 level. Standard errors clustered at state level (MSAs spanning more than one state are assigned to the state with highest share of total MSA population) are given in parentheses. The models include state fixed effects. 


\section{Concluding remarks}

This paper presents a contemporary analysis of the labour market dynamics during the first months of the COVID-19 pandemic, a crisis that affected all facets of life across the world. Research that investigates previous economic crises shows that subnational regions react very differently to the same shock (Martin, $\left.2012_{[6]}\right)$ and that regional characteristics play a role in how places fare during economic downturns. The ongoing crisis, however, is very different from all other recessions in recent history.

The analysis reveals that regional characteristics, which used to be generally associated with stronger economic performance in the past, did not offer a hedge (at least initially) against the ongoing crisis when it comes to job postings. Online vacancies in larger metropolitan areas contracted more and took longer to show signs of recovery in the first half of 2020. In a similar vein, more educated places but also places with more diverse industrial structure within major sectors fared worse. This can be partially explained by the geography and timing of the virus spread. Larger cities, which tend to have higher educational attainment and more sophisticated industrial structure, became the first hotspots of the infection in the country. Yet, the fact that these same places were slower to recover suggests other factors at play too. Part of the effect could be due to (temporary) shedding of the "nonessential" jobs, which are likely to account for a greater share of employment in larger cities.

As businesses were rapidly embracing teleworking during the pandemic, the prevalence of jobs that can be performed remotely in a region appears linked to the resilience of urban labour demand approximated by online vacancy announcements. This paper offers evidence of a positive link between the share of teleworkable jobs and growth in job postings in US MSAs. The link appears stronger in the recovery phase (May-June) of the crisis. Finally, the paper documents differences in labour demand for teleworkable and non-teleworkable occupations across different types of places.

Although the study focuses on a very short period and employs research design unable to detect causation, the analysis advances our knowledge of the ongoing changes in urban online labour demand in the US. This contributes to the efforts to document and understand regional differences in weathering the current (in many respects unique) crisis. Such understanding is the first step in designing (place-based) policies that can bolster economic resilience of a place, making it less susceptible to the negative effects of adverse events in the future.

As more data become available, studying labour market dynamics in other types of regions (rural, intermediate) will provide a better understanding of geographical differences in COVID-19 impacts across regional types but also across countries. Moreover, greater data availability will also make possible research designs that are able to identify causal links offering actionable insights for policy makers. 


\section{References}

Bartik, T. et al. (2018), Whole data: Unsuppressed county business patterns data: Version 1.0 [dataset], W.E. Upjohn Institute for Employment Research, Kalamazoo, MI.

Boschma, R. (2015), "Towards an Evolutionary Perspective on Regional Resilience", Regional Studies, Vol. 49/5, pp. 733-751, http://dx.doi.org/10.1080/00343404.2014.959481.

Brown, L. and R. Greenbaum (2017), "The role of industrial diversity in economic resilience: An empirical examination across 35 years”, Urban Studies, Vol. 54/6, pp. 1347-1366, http://dx.doi.org/10.1177/0042098015624870.

Brussevich, M., E. Dable-Norris and S. Khalid (2020), "Who will Bear the Brunt of Lockdown Policies? Evidence from Tele-workability Measures Across Countries", IMF Working Papers, No. 20/88, International Monetary Fund, Washington, DC, https://www.imf.org/en/Publications/WP/Issues/2020/06/12/Who-will-Bear-the-Brunt-ofLockdown-Policies-Evidence-from-Tele-workability-Measures-Across-49479 (accessed on 31 August 2020).

Brynjolfsson, E. et al. (2020), "COVID-19 and Remote Work: An Early Look at US Data", NBER Working Paper Series, No. 27344, National Bureau of Economic Research, Cambridge, MA, http://dx.doi.org/10.3386/w27344.

Cainelli, G., R. Ganau and M. Modica (2019), "Does related variety affect regional resilience? New evidence from Italy", Annals of Regional Science, Vol. 62/3, pp. 657-680, http://dx.doi.org/10.1007/s00168-019-00911-4.

Cho, S., J. Lee and J. Winters (2020), "Employment Impacts of the Covid-19 Pandemic Across Metropolitan Status and Size", IZA Discussion Paper, No. 13468, IZA, https://papers.ssrn.com/abstract=3648808 (accessed on 1 October 2020).

Christopherson, S., J. Michie and P. Tyler (2010), "Regional resilience: Theoretical and empirical perspectives", Cambridge Journal of Regions, Economy and Society, Vol. 3/1, pp. 3-10, https://academic.oup.com/cjres/article-abstract/3/1/3/340777 (accessed on 31 July 2020).

Corbetta, M. (forthcoming), "Exploring policy options on teleworking: Steering local economic and employment development in the time of remote work", OECD Local Economic and Employment Development (LEED) Papers, OECD Publishing, Paris.

Deller, S. and P. Watson (2016), "Did regional economic diversity influence the effects of the great recession?", Economic Inquiry, Vol. 54/4, pp. 1824-1838, http://dx.doi.org/10.1111/ecin.12323. 
Dingel, J. and B. Neiman (2020), "How Many Jobs Can be Done at Home?", NBER Working Paper Series, No. 26948, National Bureau of Economic Research, Cambridge, MA, http://dx.doi.org/10.3386/w26948.

Duranton, G. and W. Kerr (2015), "The Logic of Agglomeration", NBER Working Papers, No. 21452, National Bureau of Economic Research, Boston, MA, http://www.nber.org/papers/w21452 (accessed on 6 August 2020).

European Commission (2020), Telework in the EU before and after the COVID-19: where we were, where we head to, Joint Research Centre at European Commission.

Frenken, K., F. Van Oort and T. Verburg (2007), "Related Variety, Unrelated Variety and Regional Economic Growth", Regional Studies, Vol. 41/5, pp. 685-697, http://dx.doi.org/10.1080/00343400601120296.

Gennaioli, N. et al. (2013), "Human capital and regional development", The Quarterly Journal of Economics,, Vol. 128/1, pp. 105-164, https://academic.oup.com/qje/articleabstract/128/1/105/1840182 (accessed on 6 August 2020).

Glaeser, E. and D. Maré (2001), "Cities and Skills", Journal of Labor Economics, Vol. 19/2, pp. 316-342, http://www.journals.uchicago.edu/t-and-c (accessed on 13 December 2018).

Glaeser, E., G. Ponzetto and K. Tobio (2014), "Cities, Skills and Regional Change", Regional Studies, Vol. 48/1, pp. 7-43, http://dx.doi.org/10.1080/00343404.2012.674637.

Glaeser, E. and M. Resseger (2010), "The complementarity between cities and skills", Journal of Regional Science, Vol. 50/1, pp. 221-244, http://dx.doi.org/10.1111/j.14679787.2009.00635.x.

Isserman, A. and J. Westervelt (2006), "1.5 million missing numbers: Overcoming employment suppression in County Business Patterns data", International Regional Science Review, Vol. 29/3, pp. 311-335, http://dx.doi.org/10.1177/0160017606290359.

Kahn, L., F. Lange and D. Wiczer (2020), "Labor Demand in the Time of COVID-19: Evidence from Vacancy Postings and UI Claims", NBER Working Paper, No. 27061, National Bureau of Economic Research, Cambridge, MA, http://dx.doi.org/10.3386/w27061.

Martin, R. (2012), "Regional economic resilience, hysteresis and recessionary shocks", Journal of Economic Geography, Vol. 12/1, pp. 1-32, http://dx.doi.org/10.1093/JEG/LBR019.

Martin, R. et al. (2016), "How Regions React to Recessions: Resilience and the Role of Economic Structure", Regional Studies, Vol. 50/4, pp. 561-585, http://dx.doi.org/10.1080/00343404.2015.1136410.

OECD (2020), Capacity for remote working can affect lockdown costs differently across places, Organisation for Economic Co-operation and Development, Paris, https://read.oecdilibrary.org/view/?ref=134 134296-u9iq2m67ag\&title=Capacity-for-remote-working-can-affectlockdown-costs-differently-across-places (accessed on 28 August 2020).

OECD (2020), Cities Policy Responses, OECD, Paris, https://read.oecdilibrary.org/view/?ref=126 126769-yen45847kf\&title=Coronavirus-COVID-19-Cities-PolicyResponses (accessed on 5 October 2020). 
OECD (2020), OECD Employment Outlook 2020: Worker Security and the COVID-19 Crisis, OECD Publishing, Paris, https://dx.doi.org/10.1787/1686c758-en.

OECD (2020), Productivity gains from teleworking in the post COVID-19 era: How can public policies make it happen?, Organisation for Economic Co-operation and Development, Paris, http://www.oecd.org/coronavirus/policy-responses/productivity-gains-from-teleworking-in-thepost-covid-19-era-a5d52e99/ (accessed on 30 August 2020).

OECD Spatial Productivity Lab (2020), Regional trends in labour demand across regions. Preliminary insights..., OECD Trento Centre for Local Development, Trento, https://www.slideshare.net/OECDLEED/regional-trends-in-labour-demand-across-regionspreliminary-insights-from-online-job-postings-alexandra-tsvetkova (accessed on 7 August 2020).

Partridge, M. and A. Tsvetkova (2020), "Local ability to rewire and socioeconomic performance: Evidence from US counties before and after the Great Recession", OECD Local Economic and Employment Development (LEED) Papers, No. 2020/04, OECD, Paris, https://www.oecdilibrary.org/industry-and-services/local-ability-to-rewire-and-socioeconomicperformance 31b980f6-en (accessed on 6 August 2020).

Rothwell, J. (2020), The Unequal Distribution of Economic Damage From COVID-19, Gallup Blog, https://news.gallup.com/opinion/gallup/311714/unequal-distribution-economic-damagecovid.aspx (accessed on 8 September 2020).

Taylor, D. (2020), "A Timeline of the Coronavirus Pandemic", The New York Times, https://www.nytimes.com/article/coronavirus-timeline.html (accessed on 28 August 2020).

Watson, P. and S. Deller (2017), "Economic diversity, unemployment and the Great Recession", [10] Quarterly Review of Economics and Finance, Vol. 64, pp. 1-11, http://dx.doi.org/10.1016/j.qref.2016.12.003. 


\section{Annex A. Separate estimation for teleworkable and nonteleworkable occupations}

Table A.1. Estimation results separate for teleworkable and non-teleworkable occupations, MSAoccupation pairs

Dependent variable: growth rate in number of vacancies benchmarked against expectations based on 2019

\begin{tabular}{|c|c|c|c|c|c|c|}
\hline \multirow[b]{2}{*}{ Regional characteristics } & \multicolumn{3}{|c|}{ Teleworkable occupations } & \multicolumn{3}{|c|}{ Nonteleworkable occupations } \\
\hline & February-June & February-April & May-June & February-June & February-April & May-June \\
\hline \multirow[t]{2}{*}{ Teleworkability (employment share), 2018} & $1.079^{* *}$ & $1.265^{* * *}$ & 0.977 & $0.610^{*}$ & 0.241 & $1.064^{* *}$ \\
\hline & $(0.413)$ & $(0.372)$ & $(0.633)$ & $(0.334)$ & $(0.373)$ & $(0.503)$ \\
\hline \multirow[t]{2}{*}{ COVID-19, 2020} & 0.049 & -0.116 & 0.007 & -0.001 & -0.004 & -0.001 \\
\hline & $(0.165)$ & $(0.308)$ & $(0.101)$ & $(0.000)$ & $(0.003)$ & (0.001) \\
\hline \multirow[t]{2}{*}{ Population density, 2019} & 0.001 & 0.000 & 0.005 & $0.007^{*}$ & 0.005 & $0.012^{\star *}$ \\
\hline & $(0.005)$ & $(0.004)$ & $(0.004)$ & $(0.004)$ & $(0.004)$ & $(0.005)$ \\
\hline \multirow[t]{2}{*}{ Population growth, 2013-18 } & 0.427 & 0.451 & 1.012 & $0.876^{*}$ & 0.153 & $1.774^{\star * *}$ \\
\hline & $(0.791)$ & $(0.447)$ & $(0.784)$ & $(0.492)$ & $(0.361)$ & $(0.572)$ \\
\hline \multirow[t]{2}{*}{ Average wage growth, 2013-18 } & 0.283 & 0.297 & -0.080 & -0.270 & -0.052 & -0.495 \\
\hline & $(0.294)$ & $(0.355)$ & $(0.448)$ & $(0.304)$ & $(0.326)$ & $(0.429)$ \\
\hline \multirow[t]{2}{*}{ Unemployment, 2019} & $-3.253^{* * *}$ & $-2.559^{* *}$ & $-3.837^{\star \star *}$ & $-1.467^{*}$ & $-1.925^{\star \star *}$ & $-1.891^{*}$ \\
\hline & $(0.943)$ & $(0.974)$ & $(1.172)$ & $(0.827)$ & $(0.541)$ & $(1.047)$ \\
\hline \multirow[t]{2}{*}{ Related (intrasectoral) variety, 2016} & -6.060 & -7.232 & -15.814 & -6.135 & 7.426 & -18.169 \\
\hline & $(13.393)$ & $(11.875)$ & $(14.632)$ & $(10.287)$ & $(10.996)$ & $(13.416)$ \\
\hline \multirow[t]{2}{*}{ Unrelated (intersectoral) variety, 2016} & $-1.536^{* * *}$ & $-0.949^{* *}$ & $-1.892^{* * *}$ & $-1.617^{\star * *}$ & $-1.481^{* * *}$ & $-2.393^{* * *}$ \\
\hline & $(0.499)$ & $(0.422)$ & $(0.574)$ & $(0.357)$ & $(0.340)$ & $(0.454)$ \\
\hline \multirow[t]{2}{*}{ Human capital, 2018} & $-0.950^{* * *}$ & $-0.854^{\star \star *}$ & $-1.146^{\star \star *}$ & $-0.525^{\star \star *}$ & -0.176 & $-1.011^{* * *}$ \\
\hline & $(0.197)$ & $(0.226)$ & $(0.286)$ & $(0.162)$ & $(0.167)$ & $(0.244)$ \\
\hline \multirow[t]{2}{*}{ Constant } & $123.321^{* * *}$ & $87.417^{\star \star \star}$ & $185.264^{\star * \star}$ & $99.319^{\star \star \star}$ & $51.793^{\star *}$ & $183.814^{\star * *}$ \\
\hline & $(24.160)$ & (23.818) & (33.388) & (24.277) & $(23.208)$ & (32.757) \\
\hline Observations & 2818 & 2811 & 2801 & 4868 & 4873 & 4850 \\
\hline R-squared & 0.055 & 0.043 & 0.083 & 0.055 & 0.039 & 0.081 \\
\hline
\end{tabular}

Note: ${ }^{* * *}$ - significant at the 0.01 level; ${ }^{* *}$ - significant at the 0.05 level; ${ }^{*}$ - significant at the 0.1 level. Standard errors clustered at state level (MSAs spanning more than one state are assigned to the state with highest share of total MSA population) are given in parentheses. The models include state fixed effects. Reported results are for a subsample of observations for which the value of the dependent variable does not exceed 500 . 